\title{
Biological Control of Phytophagous Mites: A Review
}

\author{
E. Sumathi*, R. Vishnupriya, K. Ramaraju and M. Geetha \\ Department of Agriculture Entomology, Tamil Nadu Agriculture University, Coimbatore, \\ Tamil Nadu, India \\ *Corresponding author
}

\section{Keywords}

Insect Predators,

Phytoseiidae,

Acaropathogens,

Spider mites,

Biological control

Article Info

Accepted:

14 December 2018

Available Online:

10 January 2019
A B S T R A C T

Phytophagus mites are gaining importance at present since their incidence is high. Farmers rely only on acaricides and other chemical pesticides for the management of these mites results in destruction of natural enemies, pesticide resistance and pesticide residues in crops, environment pollution etc. Hence, there is a need to find alternate to manage the phytophagous mites. Exploitation of natural enemies viz., predaceous insects, predatory mites and acaropathogenic fungi are the tools in pest management programmes. Among the predatory mites, the family Phytoseiidae is known to have potential predators which have proved their efficacy against several mite pests in different crops. Classical, augmentative and conservation biocontrol programmes using some of the important biocontrol agents remained as success stories in developed countries. However, the potential use of s biocontrol agents of mite pests is yet to be exploited in developing countries like India. In this context, the present review is about updated information on predaceous insects, predatory mites and acaropathogens against phtophagous mites.

\section{Introduction}

Phytophagous mites attack most of the agricultural and horticultural crops. These pests are distributed worldwide causing loss of quality and yield or death of host plants by sucking out the cell-contents of leaf. Yield loss due to these pests may vary in different crops viz. cereals (5-50\%), sugarcane (5$20 \%)$, cotton $(20-30 \%)$, tea $(5-50 \%)$, brinjal $(13-31 \%)$ in bhendi $(23-25 \%)$, gourd $(36 \%)$, cucumber $(14 \%)$ and ornamental crops (5$15 \%$ ) (Ramaraju and Bhullar, 2013). Indiscriminate use of pesticides to control these pests resulted in destruction of natural enemies, pesticide resistance, pesticide resurgence and residues in crop and cause health hazards to consumers. These issues necessitated the development of alternative pest control strategies.

In the present scenario, the exploitation of natural enemies as a tool in pest management is essential for the sustainability and food security. Phytophagous mites are naturally controlled by predatory mites, predatory insects and acaro pathogens viz., viruses, fungi and bacteria. 


\section{Insect predators}

Insect predators of phytophagous mites are found in the following orders (Fathipour and Maleknia, 2016).

Coleoptera (Coccinellidae -Stethorus sp, Staphylinidae-Oligota sp)

Certain specialist ladybirds belonging to genus Stethorus are potential biocontrol of tetranychid mites, especially at high density of mites (Biddinger et al., 2009). The feeding potential of various Stethorus sp. has been studied by many researchers and they observed that prey was detected by contact (Fleschner, 1950). The grub sucked the inner contents of the chorion of the eggs and discarded the empty shells. The body of mobile stages of mite was first punctured and then their inner contents were sucked. It was observed to be an extra oral digestion in which salivary secretions help in liquefying the body contents of the prey. It was found that 50-100 eggs or 15-17 adults of Panonychus citri (Tanaka, 1966) or over 40 females of Tetranychus cinnabarinus (McMurtry et al., 1970) were needed per day by females of Stethorus punctillum to oviposit. The grubs and adults consumed 11.2 to 18.2 and 9.0 to 17.4 prey individuals per day, respectively under in vitro conditions. Under screen house conditions, the ratio of 1:50 predator (adult beetle)/prey (mixed population) resulted in $79.5 \%$ control of $T$. urticae at 2 days after release on okra leaves (Gulati and Kalra, 2007). Due to high feeding, reproductive capacity and synchronization with the pest population, this can rapidly reduce high mite populations to low levels. The predator is highly mobile, within minutes of release, beetles searched for mites on plants near the release site or flew to neighbouring plants. It was found to be effective for mite control on green house peppers and cucumbers. Stethorus sp. released at 400-500 beetles per tree reduced the brown mite in avocado. Clanissorews, Scymnus sp. and Brumus suturalis F. are predaceous on Oligonychus coffeae. Other potential predatory coccinellids for mites are Menochilus sexmaculatus, S. pauperculus, Coccinellasepte mpunctata, Chilochorus nigratus, Brumus suturalis, etc. Each adult female may consume 30-60 mites per day. Total fecundity ranges from 123 eggs in $S$. tridens (Fiaboe et al., 2007), 279 in $S$. punctillum (Roy et al., 2003).

Oligota pygmaea is a specialist predator, feeding on red spider mites where the larvae and adults suck their body fluid. These beetles are occasionally found in large numbers in tea fields and in such cases they contribute to the reduction of Oligonychus coffeae populations.

\section{Hemiptera (Anthocoridae)}

Anthocoris neuromus and Orius sp. are known predators of $P$. ulmi, T. urticae and $P$. citri, respectively.

\section{Neuroptera (Chrysopidae, Hemerobiidae)}

The most active predators of spider mites belong to the families Chrysopidae and Coniopterygidae. Chrysopids are another group of insects which feed on mites. Chrysoparla carnea is reported to consume 1000 to 1500 citrus red mites daily but fails to complete its life cycle on a mite diet. Chrysopa vulgaris is known to have better searching ability than Stethorus and consumes 30-50 European red mite larvae per hour.

\section{Thysanoptera (Terebrantia: Thripidae- Scolothrips sp., Aeolothrips sp.)}

Several species of thrips, Scolothrips sexmaculatus, $S$. indicus, and S. longicornis are known predators of tetranychids and reduce the pest population rapidly. The larva 
of Hyplothrips faurii consumes approximately 143 eggs of European red mite within 8-10 days of its development.

\section{Predatory mites}

Predatory mites come under families Phytoseiidae, Cheyletidae, Anystidae, Bdellidae, Erythraeidae, Tydeidae, Cunaxidae, Stigmaeidae and Ascidae. Among these families, members of Phytoseiidae are considered to be potential predators because of their specific nature, ability to feed on alternate sources of food and survive even in the absence of their prey. Because of the variety of research conducted on this family, they serve as excellent models for highlighting important concepts in biological control. However, many phytoseiid mites have comparatively shorter life cycle, equivalent reproductive potentials as of their prey, good host searching capacity and also ability to survive on relatively few prey and thus are comparatively more effective predators and promising better in management of several phytophagous mites in both greenhouses and field conditions (Dhooria, 2016).

Upon realizing the important service provided by phytoseiid mites, research began to focus on how to better use these predators for biological control. This includes their introduction, conservation, and release (Hoy, 2011). Phytoseiids are a highly diverse group of predators, making it possible to study both specialists and generalists (McMurtry et al., 2013).

\section{Biology of phytoseiid mites}

Phytoseiid mites are free-living terrestrial mites commonly found on many plant species, soil, and debris in all parts of the world, except the Antarctica. Most of the species move faster than their prey and they have same size as spider mites (200-500 microns). They are white to brown in appearance; however, body color of mites in general may vary depending upon their prey. Life cycle is also similar to spider mites and consists of egg, larva, protonymph, deutonymph and adults. Total developmental period varies from 4-12 days. It depends on prey, host plant, and environmental factors viz., temperature and humidity. The most effective species are capable of producing 2260 eggs during their life and have a tendency to lay 1-6 eggs per day during oviposition period of 10-25 days (Rahman et al., 2013). Duration of $N$. longispinosus on okra leaves, under laboratory conditions at a temperature of $27 \pm 2^{\circ} \mathrm{C}$ and relative humidity of $75 \pm$ $10 \%$. From egg to adult stage was $4.33 \pm 0.52$ days. Egg period was longer compared to other stages and it accounts for $41.12 \%$ of total developmental time. Development period of egg, larva, protonymph and deutonymh were $1.78 \pm 0.28,0.60 \pm 0.13$, $0.95 \pm 0.3$ and $1.00 \pm 0.15$ respectively. Preoviposition, oviposition and post oviposition periods were found to be $2.04 \pm 0.12,11.12 \pm$ 0.95 and $2.36 \pm 0.74$ days respectively. It laid maximum of $25.32 \pm 3.20$ eggs. Males lived longer than females with duration of $25.09 \pm$ 0.54 and $18.25 \pm 2.36$ respectively. Among the emerged adults 75 per cent were females with sex ratio of 3:1 (Rao et al., 2018).

\section{Food habits of phytoseiid mites}

Phytoseiid mites feed on a variety of food and have developed different feeding habits. They can be classified as diet specialists and diet generalists. More precisely, specialist phytoseiids feed primarily on spider mites with profuse webs such as Tetranychus urticae Koch. Generalists, may utilize and reproduce with various kinds of animal and non-animal food including mites, insects, fungi, pollen and/or plant exudates. Lifestyles of predatory mites are as follows: Type 
1, specialized predators of Tetranychusspecies represented by the Phytoseiulus species; Type II, selective predators of tetranychid mites (most frequently associated with species that produce dense webbing) represented by Galendromus, some Neoseiulus; Type III, generalist predators represented by some Neoseiulus sp., most Typhlodromus and Amblyseius sp.; Type IV, specialized pollen feeders/generalist predators represented by Euseius sp. (McCurry et al., 2013).

\section{Foraging behavior}

Foraging behavior of predators, like functional response, numerical response, mutual interference, and are usually affected by a number of factors viz., temperature, host plant, prey stage, experimental condition and pesticides.

\section{Functional response}

The functional response describes the predation rate of one predator as a function of prey density. Many predators that have been released as biocontrol agents have shown to exhibit a type II response, reaching a satiation point at certain prey density (Xiao and Fadamiro, 2010).

Laboratory studies on $N$. longispinous, revealed that the number of prey consumed by predator levelled off at densities 30-40 in case of $T$. urticae nymphs whereas, at 15-25 for adults (Rao et al., 2017).

\section{Numerical response}

Numerical response probably has more importance than the functional response. It can be defined as the change in a predator's reproductive output at varying prey densities. It may be considered as a strategy of female predators to augment their offspring at different prey densities (Cedola, et al., 2001).

\section{Mutual interference}

Mutual interference denotes the adverse influence of predator density on the instantaneous success of individual predator. Mutual interference occurs commonly in the laboratory (Farazmand et al., 2013) but it has rarely been reported in field studies. Understanding this mutual interference is necessary to predict the success of biocontrol programmes, as it assists with mass-rearing efforts and can facilitate the explanation of observed outcomes in the field.

\section{Releasing strategies of predatory mites}

Predatory mites sold in different types of packages, which represent different ways of field release. Bulk material usually comes as a tube or buckets with predatory and prey mites mixed in a carrier material viz., bran or vermiculite. Predatory mites are broadcasted on the crop viz. 1) Hand sprinkling in which predatory mites along with carrier material are transferred into plastic squeezing bottle or cardboard tubes and operator dispenses the material directly on leaves spilling it from the bottle and intervening on a row at a time. 2) Sachet method, the sachets can be hung in the crop or placed at the base of the crop. 3) Mechanical release method, the main limitation to mechanical release is that the beneficial organisms may be damaged during their handling and distribution due to possible contact with mechanical elements and abrasion against carrier materials. However, mechanical application of predatory mite is consistent with that obtained with manual application (Lanzoni et al., 2017). Releasing rate of predators is based on pest species, crop, prey density and releasing strategy. However, several workers observed that predator prey ratios between 1:10 to 1:50 were effective in reducing the spider mites below the damaging levels in green house or ornamental crops (Rao et al., 2017). 


\section{Acaro pathogens}

\section{Viruses}

Relatively few viruses are known from mites, The first record on a virus disease in a spider mite was made (Muma, 1955) and diseased mites were observed in a natural population of the citrus red mite (CRM) in Florida, USA. Infected mites showed signs of diarrhea and the cadavers were adhered to the leaf surface by a black resinous material that was excreted from the anus. The disease has later also been reported in California (Smith et al., 1959). Spherical particles inside diseased mites were observed and assumed that these were virus particles. Later, it could be demonstrated that a rod shaped, non-inclusion virus is the cause of the disease (Reed and Hall, 1972). The virus particles are approximately $194 \times 58 \mathrm{~nm}$ in size and enclosed in an envelope of circa $266 \times 111 \mathrm{~nm}$. The virus is formed inside the nuclei of epithelial cells of the midgut, but later it moves out of the nucleus, into the cytoplasm. The pathogen is transmitted when healthy mites ingest the feces of infected mites. The virus disease is common in citrus groves in California and Arizona and causes a considerable reduction in the population density of the CRM (Reed, 1981).

\section{Bacteria}

Isolates of Bacillus thuringiensis was found to show toxicity towards spider mites and house dust mites (Payne et al., 1994). B. thuringiensis strain isolated from dead two spotted spider mites, T. urticae (Jung et al., 2007). Pseudomonas putida biotype B strongly reduced egg production and no hatching of the eggs was noted (Aksoy et al., 2008). The results showed that the bacterium may be very effective in causing mortality in T. urticae populations. Further research is required to find out whether this organism may be developed to a microbial miticide.

\section{Fungi}

The first record of an entomophthoralean fungus infection in spider mites was observed by Fisher (1951) and noted adult mortality from 32 to $95 \%$ in populations of the citrus red mite Panonychus citri. A fungus was isolated from the Texas citrus mite Eutetranychus banksi and described it as Entomophthora floridana (Weiser and Muma, 1966). The fungus has since been reported from several other spider mite species: it was observed in Tetranychus tumidis on cotton in the humid subtropical regions of Florida (Saba, 1971), in T. evansi on tomato crops in Brazil (Humber et al., 1981), in T. ludeni on bean in India (Ramaseshiah, 1971), Bridge and Worland (2008) observed a Neozygites infection in the cryptostigmatic mite Alaskozetes antarcticus (Ameronothridae). This has resulted in the isolation of a Neozygites sp. that is very specific for the cassava green mite in Brazil (Delalibera et al., 1992).

Beauveria bassiana (Balsamo) Vuillemin dust formulation produced 71 per cent mortality in two spotted spider mite (Dresner, 1949). The red palm mite, Raoiella indica Hirst (Tenuipalpidae) was infected by Hirsutella sp., in Florida on palms (Pena et al., 2006). So far, Lecanicillium psalliotae Treschew has been the only other fungus reported in association with $R$. indica in Saint Lucia (ARSEF, 2009).

Cladosporium is one of the largest genera of hyphomycetes (Crous et al., 2007) isolated from insects and mites. An unidentified species of this genus was isolated from the two spotted spider mite (ARSEF 2009). Fusarium semitectum formulation suppressed the population of Zolyphagotarsonemus latus (Banks) on pepper (Mikunthan and Manjunatha, 2006). 
Beauveria, Metarhizium, Isaria and Verticillium have not been found infecting spider mites under natural conditions. Several isolates of $B$. bassiana and Metarhizium anisopliae (Metschnikoff) have been reported as pathogenic to various group of mites (Alves et al., 2002). They have been considered to have potential for practical use in inundative or inoculative approaches in agriculture (Maniania et al., 2008).

\section{References}

Ahn, J.J., Kim, K.W. and Lee, J.H. 2010. Functional response of Neoseiulus californicus (Acari: Phytoseiidae) to Tetranychus urticae (Acari: Tetranychidae) on strawberry leaves. Journal of Applied Entomology. 134: 98-104.

Aksoy, H.M., Ozman-Sullival, S.K., Ocal, H., Celik, N. and Sullivan, G.T. 2008. The effects of Pseudomonas putida biotype $\mathrm{B}$ on Tetranychus urticae (Acari: Tetranychidae). Experimental and Applied Acarology, 46: 223-230.

Alves SB, Rossi LS, Lopes RB, Tamai MA, Perera RM (2002) Beauveria bassiana yeast on agarmedium and its pathogenicity against Diatraea saccharalis (Lepidoptera: Crambidae) and Tetranychus urticae (Acari: Tetranychidae). J Invertebr Pathol 81:70-77

Amano H and Chant D A. 1977. Life history and reproduction of two species of predatory mites, Phytoseiulus persimilis Athios-Henriot and Amblyseius andersoni (Chant) (Acari: Phytoseiidae). Canadian Journal of Zoology 55: 1978-1983.

ARSEF (ARS Collection of Entomopathogenic Fungal Cultures) (2009) Catalog of species. USDA ARS Biological Integrated Pest Management Research - US Department of
Agriculture, Agricultural Research Service, Ithaca, p 435.

Biddinger D J., Donald C. Weber B, Larry A. Hull. 2009. Coccinellidae as predators of mites: Stethorini in biological control. Biological Control 51 268-283.

Cedola C V, Sanchez N E and Liljesthrom G G. 2001. Effect of tomato leaf hairiness on functional and numerical response of Neoseiulus californicus (Acari: Phytoseiidae). Experimental and Applied Acarology 25: 819-831.

Crous, P.W., Braun, U., Schubert, K., Groenewald, J.Z. 2007. Delimiting Cladosporium from morphologically similar genera. Stud Mycol. 58:33-56

Dhooria, M.S. 2016. Fundamentals of applied acarology. Springer, Singapore. pp 20.

Fathipour, Y. and Maleknia, B. 2016. Mite Predators. In: Ecofriendly Pest Management for Food Security. Omkar (ed.). San Diego, USA, Elsevier. 329366.

Fiaboe, K.K.M., Gondim, M.G.C., de Moraes, G.J., Ogol, C.K.P.O. and Knapp, M. 2007. Bionomics of the acarophagous ladybird beetle Stethorus tridens fed Tetranychus evansi. Journal of Applied Entomology. 131: 355-361.

Fisher, F.E. 1951. An Entomophthora attacking citrus red mite. The Florida Entomologist, 34: 83-88.

Fleschner, C.A. 1950. Studies on searching capacity on the larvae of three predators of the citrus red mite (Paratetranychus citri) (Stethorus picipes, Conwentzia hageni, Chrysopa claifornicus). Hilgardia. 20: 233-265.

Fournier, D., Millot, P. and Pralavorio, M. 1985. Rearing and mass production of the predatory mite, Phytoseiulus persimilis. Entomologia Experimentalis et Applicata. 38: 97-100.

Hoy, M.A. 2011. The Phytoseiidae: effective natural enemies. In: Agricultural acarology: introduction to Integrated 
Mite Management. Taylor and Francis Group, Boca Raton. pp 159-184.

Jung, Y.C., Mizuki, E., Akao, T., and Cote, J. C. 2007. Isolation and characterization of a novel Bacillus thuringiensis strain expressing a novel crystal protein with cytocidal activity against human cancer cells. Journal of Applied Microbiology, 103: 65-79.

Maniania, N.K., Bugeme, D.M., Wekesa, V.W., Delalibera, I. and Knapp, M. (2008) Role of entomopathogenic fungi in the control of Tetranychus evansi and Tetranychus urticae (Acari: Tetranychidae), pests of horticultural crops. Exp Appl Acarol. 46:259-274.

McMurtry, J.A., Huffaker, C.B. and Van de Vrie, M. 1970. Ecology of tetranychid mites and their natural enemies: a review. In. Tetranychid enemies: their biological characters and the impact of spray practices. Hilgardia. 40: 331-390.

McMurtry, J.A, De Moraes, G.J. and Sourassou, N.F. 2013. Revision of the lifestyles of phytoseiid mites (Acari: Phytoseiidae) and implications for biological control strategies. Systematic and Applied Acarology. 18: 297-320.

Mikunthan, G., Manjunatha, M. 2006. Fusarium semitectum, a potential mycopathogen against thrips and mites in chilli, Capsicum annum. Commun Agric Appl Biol Sci. 71:449-463.

Morales-Ramos, Alfredo, J. and Maria Rojas, G. 2014. A modular cage system design for continuous medium to large scale in vivo rearing of predatory mites (Acari: Phytoseiidae). Psyche: A Journal of Entomology. Id. 596768.

Muma, M.H. 1955. Factors contributing to the natural control of citrus insects and mites in Florida. Journal of Economic Entomology, 48: 432-438.

Pena, J.E, Mannion, C.M., Howard, F.W., Hoy, M.A. 2006. Raoiella indica (Prostigmata: Tenuipalpidae): the red palm mite: a potential invasive pest of palms and bananas and other tropical crops in Florida. University of Florida IFAS Extension, ENY-837, 414.

Payne, J., Cannon, R. J. C. and Ralph, A. L. 1994. Bacillus thuringiensis isolates for controlling acarides (20pp). US Patent 5,350,576.

Rahman, V.J., Azariah, B., Amsalingam, R., and Samy, A. 2013. Life table and predation of Neoseiulus longispinosus (Acari: Phytoseiidae) on Oligonychus coffeae (Acari: Tetranychidae) infesting tea. Experimental and Applied Acarology. 60: 229-240.

Ramaseshiah, G. 1971. Occurrence of an Entomophthora on tetranychid mites in India. Journal of Invertebrate Pathology, 24: 218-223.

Ramaraju, K. and Bhullar, M.B. 2013. Novel approaches for management of phytophagus mites. In: Integrated pest management. (Eds) Dhavan, A.K., Balwinder, S., Manmeet, B.B and Arora, R. Scientific Publishers, Jodhpur. pp 600-616.

Rao, K.S., Vishnupriya, R. and Ramaraju, K. 2017. Evaluation of predaceous mite, Neoseiulus longispinosus (Evans) (Acari: Phytoseiidae) as a predator of the two Spotted spider mite, Tetranychus urticae Koch (Acari: Tetranychidae). Journal of Experimental Zoology India. 20: 13431347.

Rao, K.S, Vishnupriya, R. and Ramaraju, K. 2018. Life history of predatory mite, Neoseiulus longispinosus (Evans) cultured on prey mite, Tetranychus urticae Koch. In: International Conference on Sustainable Agriculture, Energy, Environment and Technology, Maharshi Dayanand University, Rohtak. p 323.

Reed, D.K. 1981. Control of mites by nonoccluded viruses. In: Microbial control 
of pests and plant Diseases. Burges, H.D. (Ed.), 1970-1980 (pp. 427-432). New York: Academic Press.

Reed, D.K., and Hall, I.M. 972). Electron microscopy of a rod-shaped noninclusion virus infecting the citrus red mite, Panonychus citri. Journal of Invertebrate Pathology, 20: 272-278.

Roy, M., Brodeur, J. and Cloutier, C. 2003. Effect of temperature on intrinsic rates of natural increase (rm) of a coccinellid and its spider mite prey. BioControl. 48 : 57- 72 .

Saba, F. 1971. Population dynamics of some tetranychids in subtropical Florida. In: Proceedings 3rd International Congress of Acarology. Prague, The Hague, Junk. p. 237-240.

Vacante, V. and Firullo, V. 1983. Observations on the population dynamics of Phytoseiulus persimilis
(Acarina: Phytoseiidae) on the roses in cold green houses in the Kagura Province in Sicity. Rijksuniversitait Genetics, 48: 263-272.

Van Der Geest, L.P.S., Elliot, S.L., Breeuwer, J.A.J. and Beerling, E.A.M. 2000 Diseases of mites. Exp Appl Acaro.l 24:497-560.

Weiser, J., and Muma, M.H. 1966. Entomophthora floridana n. sp. (Phycomycetes: Entomophthoraceae), a parasite of the Texas citrus mite Tetranychus banksi. The Florida Entomologist, 49: 155-159.

Xiao, Y. and Fadamiro, H.Y. 2010. Functional responses and prey-stage preferences of three species of predacious mites (Acari: Phytoseiidae) on citrus red mite, Panonychus citri (Acari: Tetranychidae). Biological Control. 53: 345-352.

\section{How to cite this article:}

Sumathi, E., R. Vishnupriya K. Ramaraju and Geetha, M. 2019. Biological Control of Phytophagous Mites: A Review. Int.J.Curr.Microbiol.App.Sci. 8(01): 2153-2160. doi: https://doi.org/10.20546/ijcmas.2019.801.225 